\title{
Evaluation of the cardiovascular effects of varenicline in rats
}

\author{
This article was published in the following Dove Press journal: \\ Drug Design, Development and Therapy \\ 22 October 2015 \\ Number of times this article has been viewed
}

\author{
Engin Burak Selçuk' \\ Meltem Sungu ${ }^{2}$ \\ Hakan Parlakpinar ${ }^{3}$ \\ Necip Ermiș ${ }^{4}$ \\ Elif Taslıdere ${ }^{5}$ \\ Nigar Vardı ${ }^{5}$ \\ Murat Yalçınsoy ${ }^{6}$ \\ Mustafa Sagır ${ }^{3}$ \\ Alaaddin Polat ${ }^{7}$ \\ Mehmet Karatas ${ }^{8}$ \\ Burcu Kayhan-Tetik' \\ 'Department of Family Medicine, \\ ${ }^{2}$ Inonu University Medical Faculty, \\ Malatya, Turkey; ${ }^{3}$ Department of \\ Pharmacology, ${ }^{4}$ Department of \\ Cardiology, ${ }^{5}$ Department of Histology \\ and Embryology, ${ }^{6}$ Department of \\ Pulmonary Medicine, ${ }^{7}$ Department of \\ Physiology, ${ }^{8}$ Department of Medical \\ Ethics, Inonu University Medical \\ Faculty, Malatya, Turkey
}

Background: Cardiovascular disease is an important cause of morbidity and mortality among tobacco users. Varenicline is widely used worldwide to help smoking cessation, but some published studies have reported associated cardiovascular events.

Objective: To determine the cardiovascular toxicity induced by varenicline in rats.

Materials and methods: We randomly separated 34 rats into two groups: 1) the control group (given only distilled water orally, $\mathrm{n}=10$ ) and the varenicline group (given $9 \mu \mathrm{g} / \mathrm{kg} / \mathrm{day}$ varenicline on days $1-3,9 \mu \mathrm{g} / \mathrm{kg}$ twice daily on days $4-7$, and $18 \mu \mathrm{g} / \mathrm{kg}$ twice daily on days $8-90$ [total 83 days], $n=24$ ). Each group was then subdivided equally into acute and chronic subgroups, and all rats in these groups were euthanized with anesthesia overdose on days 45 and 90, respectively. Body and heart weights, hemodynamic (mean oxygen saturation, mean blood pressure, and heart rate, electrocardiographic (PR, QRS, and QT intervals) biochemical (oxidants and antioxidants), and histopathological analyses (including immunostaining) were performed.

Results: Acute varenicline exposure resulted in loss of body weight, while chronic varenicline exposure caused heart weight loss and decreased mean blood pressure, induced lipid peroxidation, and reduced antioxidant activity. Both acute and chronic varenicline exposure caused impairment of mean oxygen saturation. QT interval was prolonged in the chronic varenicline group, while PR interval prolongation was statistically significant in both the control and acute varenicline groups. Caspase-9 activity was also significantly increased by chronic exposure. Moreover, histopathological observations revealed severe morphological heart damage in both groups.

Conclusion: Adverse effects of chronic varenicline exposure on cardiovascular tissue were confirmed by our electrocardiographic, biochemical, and histopathological analyses. This issue needs to be investigated with new experimental and clinical studies to evaluate the exact mechanism(s) of the detrimental effects of varenicline. Physicians should bear in mind the toxic effects of varenicline on the cardiovascular system when prescribing it for smoking cessation.

Keywords: varenicline, smoking, cardiovascular, rat, electrocardiogram, histopathological evaluation

\section{Introduction}

Varenicline is a first-line and widely used medication for smoking cessation. It is a partial agonist of the $\alpha 4 \beta 2$ nicotinic acetylcholine receptor (nAChR) and a full agonist of the $\alpha 7$ nAChR. ${ }^{1,2}$ The efficacy of varenicline has been demonstrated previously in clinical trials..$^{3,4}$ It has superior short-term efficacy compared with other smoking cessation therapies such as bupropion and nicotine replacement therapy, ${ }^{5}$ and a long-term study showed that varenicline produced fewer withdrawal symptoms and had a longer continuous abstinence rate compared with nicotine replacement therapy. ${ }^{6}$ The most common adverse effects (AEs) of varenicline therapy are headache, nausea, nightmares, and insomnia. ${ }^{3,4}$ Other psychiatric effects have also been identified from post-marketing surveillance of varenicline, and the product information includes warnings about the risk of neuropsychiatric effects.
Correspondence: Engin Burak Selçuk Department of Family Medicine, Inonu University Medical Faculty, Elazig Road I0th km, 44325, Malatya, Turkey Tel +9042234 l 0660 ext 5430 Fax +904223410728

Email drenginselcuk@hotmail.com 
In 2011, the US Food and Drug Administration (FDA) communicated findings from its review of a clinical trial that included approximately 700 patients with cardiovascular disease (CVD), and reported an increased risk of cardiovascular events (CEs) in patients taking varenicline compared with placebo. ${ }^{7,8}$ Following this, a systematic review and meta-analysis of the risk of serious CEs associated with varenicline was published. ${ }^{9}$ A follow-up meta-analysis found the difference between varenicline and placebo to be statistically and clinically insignificant. ${ }^{10,11}$ At the request of the FDA, the drug manufacturer (Pfizer, Inc, New York, NY, USA) recently conducted a meta-analysis based on major adverse cardiovascular events, defined as cardiovascular death, non-fatal myocardial infarction, and non-fatal stroke. ${ }^{12}$ Using individual patient data from industry-sponsored randomized controlled trials, the study found the hazard ratio (HR) was not significant (HR, 1.95; 95\% confidence interval [CI], 0.79-4.82). The most recent FDA safety communication on varenicline, ${ }^{12}$ from December 2012, indicated that the events were uncommon in both active and placebo drug conditions, and that the increased risk was not statistically significant. Similarly, an FDA mini-sentinel evaluation assessing CEs among 89,519 varenicline users and 113,378 bupropion users found no difference in CE risk between varenicline and bupropion (incidence rate ratio, 1.02; 95\% CI, 0.71-1.47). ${ }^{13}$

To date, there have been limited preclinical studies investigating the cardiovascular effects of varenicline, and the results have been inconsistent. ${ }^{7,-11}$ Therefore, in the current study, we focused on the cardiac effects of varenicline on animal models in an attempt to resolve this inconsistency. In the present study, we aimed to determine the acute and chronic toxic effects of varenicline on the heart and aortic tissue of rats, so we investigated the oxidative stress of heart and aortic tissue, hemodynamic parameters, mean oxygen saturation $\left(\mathrm{SO}_{2} \%\right.$ ), systemic $\mathrm{BP}$, heart rate (HR [including electrocardiogram $\{\mathrm{ECG}\}$ analysis]), and organ weights, as well as the histopathological changes and apoptotic events in rat cells.

\section{Materials and methods Animals}

For this study, Wistar albino rats, aged 10-12 weeks and weighing 250-300 g, were housed in an air-conditioned room with 12-hour light/dark cycles, with temperature $\left(22^{\circ} \mathrm{C} \pm 2{ }^{\circ} \mathrm{C}\right)$ and relative humidity $(65 \%-70 \%)$ kept constant. The rats were fed standard commercial pellets and water ad libitum. All experimental protocols were approved by the
Inonu University School of Medicine Animal Care and Use Committee (2209/A-2012), Malatya, Turkey.

\section{Experimental protocol}

In total, 34 rats were studied, which were randomly divided into two groups: 1) the control group $(C ; n=10)$ and the 2 ) varenicline group $(V ; n=24)$. The rats in each group were then subdivided equally into acute and chronic control and varenicline treatment groups. The control rats were orally administered distilled water only. The duration and doses of varenicline (Champix ${ }^{\circledR} 1 \mathrm{mg}$ tablets; Pfizer, Inc) were based on the varenicline treatment scheme for humans, by converting human doses to equivalent animal doses by means of dose-equivalence tables. ${ }^{14}$ Varenicline was administered orally as follows: $9 \mu \mathrm{g} / \mathrm{kg} /$ day on days $1-3,9 \mu \mathrm{g} / \mathrm{kg}$ twice daily on days $4-7$, and $18 \mu \mathrm{g} / \mathrm{kg}$ twice daily on days $8-90$ (the latter treatment being a total of 83 days). Overdose of ketamine and xylazine anesthesia was used to euthanize the rats in the acute groups $(\mathrm{C} 1[\mathrm{n}=5]$ and $\mathrm{V} 1[\mathrm{n}=12])$ on day 45 , and the rats in the chronic groups $(\mathrm{C} 2[\mathrm{n}=5]$ and V2 [n=12]) on day 90 . The duration of the experiment was chosen according to the varenicline human-treatment program of the Turkish Ministry of Health. ${ }^{14}$ The heart and vessel (thoracic aorta) tissues were quickly removed for biochemical and histopathological analysis.

\section{Biochemical analysis}

Determination of tissue thiobarbituric acid reactive substances as a marker of malondialdehyde content The thiobarbituric acid reactive substances (TBARS) level was used as a marker of malondialdehyde (MDA). The TBARS content of the homogenates was determined spectrophotometrically using the thiobarbituric acid reaction. ${ }^{15}$ For this reaction, $3 \mathrm{~mL}$ of $1 \%$ phosphoric acid and $1 \mathrm{~mL}$ $0.6 \%$ thiobarbituric acid solution were added to $0.5 \mathrm{~mL}$ of plasma in a tube. The mixture was heated in boiling water for 45 minutes. After the mixture had cooled, the color was extracted with $4 \mathrm{~mL}$ of $n$-butanol. The absorbance was measured using a spectrophotometer (UV-1601; Shimadzu, Kyoto, Japan) at $532 \mathrm{~nm}$. The amount of lipid peroxide per TBARS of lipid peroxidation was calculated, and results were expressed in nanomoles per gram ( $\mathrm{nmol} / \mathrm{g}$ ) of tissue according to a standard graph, which was prepared using measurements of standard solutions of 1,1,3,3-tetramethoxypropane.

\section{Determination of superoxide dismutase}

Total (Cu-Zn and Mn) superoxide dismutase (SOD) (enzyme nomenclature [EC] 1.15.1.1) activity was determined based 
on the method of Sun et al. ${ }^{16}$ The principle of this method is the inhibition of nitroblue tetrazolium (NBT) reduction by the xanthine-xanthine oxidase system as a superoxide $\left(\mathrm{O}_{2}^{-}\right)$generator. One unit of SOD was defined as the enzyme amount causing 50\% inhibition in the NBT reduction rate. SOD activity was expressed as units per milligram protein (U/mg protein).

\section{Determination of glutathione peroxidase}

Determination of glutathione peroxidase (GPx) activity (EC 1.6.4.2) was measured using the method of Paglia and Valentine. ${ }^{17}$ An enzymatic reaction was initiated by adding $\mathrm{H}_{2} \mathrm{O}_{2}$ to a tube containing nicotinamide adenine dinucleotide phosphate (NADPH), reduced glutathione (GSH), sodium azide, and glutathione reductase, and the change in absorbance at $340 \mathrm{~nm}$ was monitored by a spectrophotometer. Activity was expressed in units per gram protein (U/g protein).

\section{Determination of myeloperoxidase activity}

Myeloperoxidase (MPO) (EC 1.11.1.7) activity was determined by using a 4-aminoantipyrine/phenol solution as the substrate for MPO-mediated oxidation by $\mathrm{H}_{2} \mathrm{O}_{2}$, and the change in absorbance at $510 \mathrm{~nm}$ was recorded. ${ }^{18}$ One unit of MPO activity was defined as the amount causing degradation of $1 \mu \mathrm{mol} \mathrm{H}_{2} \mathrm{O}_{2} / \mathrm{min}$ at $25^{\circ} \mathrm{C}$. The results were expressed as $\mathrm{mU} / \mathrm{g}$ protein.

\section{Determination of catalase}

Catalase (CAT) (EC 1.11.1.6) activity was determined as previously described by Aebi. ${ }^{19}$ The principle of the assay is based on the determination of the rate constant $(k$, per second) or the $\mathrm{H}_{2} \mathrm{O}_{2}$ decomposition rate at $240 \mathrm{~nm}$. Results were expressed in $k$ per gram protein ( $k / g$ protein).

\section{Determination of GSH content}

The GSH content in the heart tissue, existing as non-protein sulfhydryls, was analyzed following a previously described method. ${ }^{20}$ Aliquots of tissue homogenate were mixed with distilled water and 50\% trichloroacetic acid in glass tubes, and spun in a centrifuge at 3,000 rpm for 15 minutes. The supernatants were mixed with Tris buffer $(0.4 \mathrm{M}, \mathrm{pH} 8.9)$, and 5,5'-dithiobis-(2-nitrobenzoic acid) (DTNB, 0.01 M) was added. After the reaction mixture was shaken, its absorbance was measured at $412 \mathrm{~nm}$ within 5 minutes by the addition of DTNB against blank with no homogenate. The absorbance values were extrapolated from the standard curve $(12,24,36$, 48,60 , and $72 \mu \mathrm{g} / \mathrm{mL}$ ) and were expressed as micromoles of $\mathrm{GSH}$ per gram $(\mu \mathrm{mol} / \mathrm{g})$ of tissue.

\section{Histological examination}

For histological evaluation, the samples of heart and aortic tissue were fixed in 10\% formalin. Sections of the heart tissue were cut at $5 \mu \mathrm{m}$, mounted on slides, and were stained with hematoxylin and eosin (HE). An overall score of cardiac damage severity was semiquantitively assessed by counting cells with eosinophilic cytoplasm and darker nuclei, cytoplasmic vacuolization, infiltration, and congestion. The microscopic score of each tissue was calculated as the sum of the scores given to each criterion $(0$, none; 1 , mild; 2, moderate; 3 , severe).

For immunohistochemical analysis, thick sections of heart were taken and were placed onto polylysine-coated slides. After rehydrating, the samples were transferred to citrate buffer ( $\mathrm{pH} 7.6$ ) and were heated in a microwave oven for 20 minutes. After cooling for 20 minutes at room temperature, the sections were washed with phosphate-buffered saline (PBS), then transferred to $0.3 \% \mathrm{H}_{2} \mathrm{O}_{2}$ for 7 minutes, and were then washed again with PBS. Sections were incubated with primary rabbit-monoclonal cysteine aspartate-specific proteinases-3 (caspase-3) (Thermo Fisher Scientific, Waltham, MA, USA) and caspase-9 (Thermo Fisher Scientific) antibody for $30 \mathrm{~min}-$ utes, then rinsed in PBS, and were incubated with biotinylated goat anti-polyvalent antibody for 10 minutes, followed by streptavidin peroxidase for 10 minutes at room temperature. This staining procedure was completed with chromogen plus substrate for 15 minutes, then slides were counterstained with Mayer's hematoxylin for 1 minute, rinsed in tap water, and were dehydrated. Caspase- 3 and caspase- 9 kits were used in accordance with the manufacturer's instructions, except for minor revision. Caspase-3- and caspase-9-positive cells stained a brown color. Stained caspase- 3 and caspase- 9 (positive) cells were counted under $\times 40$ magnification.

Sections of aortic tissue were cut at $5 \mu \mathrm{m}$ and were mounted on slides stained with HE and orsein, and then the thickness of the tunica media was measured. For this morphometric analysis, each slide was observed under $\times 40$ magnification, and five points of maximum medial thickening were selected randomly. Tissues were examined using a Leica DFC280 light microscope and a Leica Q Win Image Analysis system (Leica Microsystems, Wetzlar, Germany).

\section{Hemodynamic parameters}

$\mathrm{SO}_{2} \%$, systemic mean blood pressure (MBP), and HR measured at the cannulated carotid artery were monitored and recorded by an MP-100 A-CE recorder (BIOPAC, Goleta, CA, USA). In addition, ECG signal activity was recorded for at least 3 minutes with a sampling frequency of $500 \mathrm{~Hz}$ 
under anesthesia, using disposable electrodes attached to the thorax of the rat. After the recordings were completed successfully, the ECG traces were analyzed visually to assess HR and major ECG anomalies according to the diagnostic criteria described in the Lambeth Conventions. ${ }^{21}$ In addition, the analysis also evaluated the high-precision measurements of the duration and fluctuations in PR, QRS, and QT waves, and variability between the groups.

\section{Statistical analysis}

For detecting even minor effects, the required sample sizes used in this experiment were identified using statistical power analysis. The sample sizes necessary for a power of 0.80 were estimated using NCSS software. Statistical analyses were performed with the SPSS for Winversion 16.0 program (SPSS Inc, Chicago, IL, USA).

The normality of the distribution was confirmed using the Kolmogorov-Smirnov test. Based on the results obtained from the normality test, one-way analysis of variance (ANOVA) or the Kruskal-Wallis $H$-test were used, as appropriate, for the statistical analysis. Multiple comparisons were carried out using Tamhane's test (for non-homogeneous variances) after the ANOVA test. The results were expressed as mean \pm standard deviation (SD) for biochemical analysis and cardiac rhythms. If the Kruskal-Wallis $H$-test was significant, a Conover test was also carried out for body weight (BW), heart weight (HW), $\mathrm{SO}_{2} \%$, and histopathological results. For this test, the values were expressed as medians (ranges). Values of $P<0.05$ were regarded as statistically significant.

\section{Results}

Neither varenicline exposure nor anesthesia treatment caused any animal mortality. All rats in the groups survived to the end of the experiment.

\section{Biochemical results and organ weight assessment} BW and HW, oxidant/antioxidant parameters (MDA, SOD, CAT, GPx, GSH, and MPO), and $\mathrm{SO}_{2} \%$ are presented in
Tables 1 and 2 . In the experiment to assess acute varenicline exposure, varenicline led to a significant decrease in $\mathrm{SO}_{2} \%$ and BW compared with the control group. In addition, there was a numerical increase in CAT levels and MPO activities and a numerical decrease in MDA, SOD, GSH, and GPx activities and HW, but these alterations did not reach significant levels. In the chronic exposure group, varenicline caused significant changes in MDA, MPO, CAT, GSH, and GPx levels, causing an increase in MDA and MPO, and a decrease in CAT, GSH, and GPx levels compared with the control rats. There were significant differences between chronic and acute varenicline treatment with regard to MDA, CAT, GPx, GSH, and MPO levels. For heart tissue, MDA and MPO levels were significantly higher, and CAT, GPx, and GSH levels were significantly lower in the chronic than in the V1 group.

\section{Assessment of ECG traces}

Parameters of cardiac rhythms derived from ECG traces of rat groups are presented in Table 3. In brief, PR interval prolongation in the V2 group was statistically significant compared with both the control and the V1 groups. For QRS interval, there was no statistically significant difference between the acute and V2 groups $(P>0.05)$, while QT interval was significantly prolonged in the V2 group compared with the C2 group.

\section{Histopathological results}

The hearts of rats in the $\mathrm{C} 1$ and $\mathrm{C} 2$ groups showed normal heart structure, and there were no lesions (Figure 1A, B), whereas in the V1 and V2 groups, the hearts showed severe morphological damage. Cells with eosinophilic cytoplasm and darker nuclei were also seen in the V1 and V2 groups (Figure 2A, B), and some of the cardiomyocytes showed intracytoplasmic vacuoles (Figure 2C, D). Moreover, hemorrhage (Figure 2E, F) and inflammatory cell infiltration (Figure 2G, H) were apparent in the V1 and V2 groups. Histopathological score was found to be significantly

Table I Summary of body and heart weight, mean oxygen saturation $\left(\mathrm{SO}_{2} \%\right)$, heart rate (HR), and mean arterial blood pressure (MBP)

\begin{tabular}{llllll}
\hline Groups & Body weight $(\mathbf{k g})$ & Heart weight $(\mathbf{m g})$ & SO $_{2}(\%)$ & HR $(\mathrm{beats} / \mathbf{m i n})$ & MBP $(\mathbf{m m H g})$ \\
\hline $\mathrm{Cl}$ & $344(320-360)$ & $1.13(1.05-1.28)$ & $96(94-98)$ & $307.2 \pm 73.3$ & $94.6 \pm 5.77$ \\
$\mathrm{VI}$ & $281.5(260-290)^{\mathrm{a}}$ & $0.99(0.89-1.94)$ & $93(90-97)^{\mathrm{a}}$ & $285.63 \pm 31.8$ & $101.63 \pm 12.77$ \\
$\mathrm{C} 2$ & $330(260-380)$ & $0.86(0.72-1.21)$ & $96(91-98)$ & $272.8 \pm 42.29$ & $121.6 \pm 5.08$ \\
$\mathrm{~V} 2$ & $291(247-315)$ & $0.92(0.77-1.02)^{\mathrm{c}}$ & $82(75-92)^{\mathrm{b}, \mathrm{c}}$ & $324.92 \pm 135.8$ & $96.25 \pm 11.55^{\mathrm{b}}$ \\
\hline
\end{tabular}

Notes: Data are expressed as mean \pm SD or median (range). aSignificant $P$-values $(P<0.05)$ vs acute control group; ${ }^{b}$ significant $P$-values $(P<0.05)$ vs chronic control group; csignificant $P$-values $(P<0.05)$ vs acute varenicline group.

Abbreviations: $\mathrm{Cl}$, control group for acute varenicline treatment $(\mathrm{n}=5)$; $\mathrm{C} 2$, control group for chronic varenicline treatment ( $\mathrm{n}=5$ ); $\mathrm{VI}$, acute varenicline treatment group $(\mathrm{n}=12)$; V2, chronic varenicline treatment group $(\mathrm{n}=12)$; SD, standard deviation; vs, versus; min, minutes. 
Table 2 Levels of malondialdehyde (MDA), superoxide dismutase (SOD), catalase (CAT), glutathione peroxidase (GPx), reduced glutathione (GSH), and myeloperoxidase (MPO) in heart tissue

\begin{tabular}{lllllll}
\hline Groups & $\begin{array}{l}\text { MDA } \\
\text { (nmol/g tissue) }\end{array}$ & $\begin{array}{l}\text { SOD } \\
\text { (U/mg protein) }\end{array}$ & $\begin{array}{l}\text { CAT } \\
(\mathbf{k U} / \mathbf{m g} \text { protein) }\end{array}$ & $\begin{array}{l}\text { GPx } \\
\text { (IU/mg protein) }\end{array}$ & $\begin{array}{l}\text { GSH } \\
\text { (nmol/mL) }\end{array}$ & $\begin{array}{l}\text { MPO } \\
\text { (U/mg protein) }\end{array}$ \\
\hline $\mathrm{Cl}$ & $7.43 \pm 2.05$ & $63.96 \pm 2.46$ & $23.48 \pm 2.32$ & $7.65 \pm 1.74$ & $0.56 \pm 0.09$ & $24.21 \pm 5.22$ \\
$\mathrm{VI}$ & $5.56 \pm 1.47$ & $57.5 I \pm 8.78$ & $28.30 \pm 7.39$ & $7.23 \pm 2.57$ & $0.46 \pm 0.08$ & $26.70 \pm 9.10$ \\
$\mathrm{C} 2$ & $7.23 \pm 1.53$ & $59.95 \pm 7.16$ & $22.48 \pm 3.03$ & $7.84 \pm 1.87$ & $0.62 \pm 0.06$ & $24.21 \pm 5.35$ \\
V2 & $14.95 \pm 3.80^{\mathrm{a}, \mathrm{b}}$ & $58.19 \pm 17.77$ & $10.22 \pm 3.14^{\mathrm{a}, \mathrm{b}}$ & $4.09 \pm 0.97^{\mathrm{a}, \mathrm{b}}$ & $0.34 \pm 0.07^{\mathrm{a}, \mathrm{b}}$ & $46.21 \pm 7.83^{\mathrm{a}, \mathrm{b}}$ \\
\hline
\end{tabular}

Notes: Data are expressed as mean \pm SD. aSignificant $P$-values $(P<0.05)$ vs chronic control group; bsignificant $P$-values $(P<0.05)$ vs acute varenicline group.

Abbreviations: $\mathrm{Cl}$, control group for acute varenicline treatment $(\mathrm{n}=5)$; $\mathrm{C} 2$, control group for chronic varenicline treatment $(\mathrm{n}=5)$; $\mathrm{VI}$, acute varenicline treatment group $(n=12)$; V2, chronic varenicline treatment group $(n=12)$; SD, standard deviation; vs, versus.

increased in the V1 and V2 groups compared with the control groups $(P<0.05)$. In addition, histopathological score was significantly increased in the V2 group compared with the V1 group $(P<0.05)$. The scores for semiquantitative analysis of the heart tissue are presented in Table 4.

\section{Caspase- 3 and caspase- 9 activity assay}

There was no caspase-3 immunoreactivity seen in any of the heart cells in any of the groups (Figure 3A-D). In addition, caspase-9-positive cells were not seen in the $\mathrm{C} 1$ and $\mathrm{C} 2$ groups (Figure 4A, B), but a few caspase-9-positive heart cells were seen in the experimental (V1 and V2) groups (Figure 4C, D). Caspase-9 activity was significantly increased in the V2 group compared with the V1 group. Human tonsil was used as positive control tissue (Figure 5A, B). The results of staining with caspase- 9 are given in Table 5.

\section{Aorta}

The tunica intima, media, and adventitia of the control group's aortic specimens showed normal histology. The intima of the aorta was composed of a continuous layer of endothelial cells in these groups (Figure 6A, B). The mean thickening of the tunica media was measured as $88.08 \pm 3.00 \mu \mathrm{m}$ in the $\mathrm{V} 1$ and $92.88 \pm 2.85 \mu \mathrm{m}$ in the $\mathrm{V} 2$ groups. Tunica media thickness was found to be significantly increased in the V1 and V2 groups

Table 3 Parameters of cardiac rhythms derived from ECG traces of rat groups

\begin{tabular}{llll}
\hline Groups & PR $(\mathbf{m s})$ & QRS $(\mathbf{m s})$ & QT $(\mathbf{m s})$ \\
\hline $\mathrm{Cl}$ & $43.6 \pm 3.58$ & $34.8 \pm \mathrm{I} . \mathrm{I}$ & $72.8 \pm 2.68$ \\
$\mathrm{VI}$ & $42.2 \pm 2.44$ & $35.3 \pm \mathrm{I} .0 \mathrm{I}$ & $71.5 \pm 2.38$ \\
$\mathrm{C} 2$ & $42.8 \pm 1.79$ & $34.8 \pm \mathrm{I} . \mathrm{I}$ & $74.8 \pm 2.68$ \\
$\mathrm{~V} 2$ & $47.8 \pm 2.48^{\mathrm{a}, \mathrm{b}}$ & $35.2 \pm \mathrm{I} .59$ & $79.8 \pm 6.9^{\mathrm{b}}$ \\
\hline
\end{tabular}

Notes: Data are expressed as mean \pm SD. aSignificant $P$-values $(P<0.05)$ vs chronic control group; 'significant $P$-values $(P<0.05)$ vs acute varenicline group. PR, QRS, and $\mathrm{QT}$ values are expressed as the gross mean $\pm \mathrm{SD}$.

Abbreviations: $\mathrm{Cl}$, control group for acute varenicline treatment $(\mathrm{n}=5)$; $\mathrm{C} 2$, control group for chronic varenicline treatment $(n=5)$; VI, acute varenicline treatment group ( $n=I I)$; V2, chronic varenicline treatment group $(n=12)$; ECG, electrocardiogram; SD, standard deviation; vs, versus; ms, milliseconds. compared with the control groups $(P<0.05)$ (Figure 6C, D). However, the difference between the V1 and V2 groups was not statistically significant $(P>0.05)$.

The tunica media was characterized by numerous distinct elastic laminae, which were found to be wavy and were arranged concentrically in sections stained with orsein (Figure 7A, B). By contrast, in the media of the aorta of varenicline-administered rats, the elastic lamellae were smooth and fragmented (Figure 7C, D). The results of the semiquantitative morphometric analysis of the aorta are reported in Table 6 .

\section{Discussion}

Smoking is a common public health problem, and various medical therapies have been developed to reduce smoking addiction. Varenicline is the most recently developed and most widely used drug for smoking cessation. It is a partial agonist of the nicotinic acetylcholine receptor $\alpha 4 \beta 2$ Karlape. ${ }^{22}$ Varenicline has some AEs; however, reports of cardiovascular AEs are still very controversial. Cahill et a ${ }^{1}$ found varenicline to be twice as effective as unassisted smoking cessation, and reported that the estimated number of patients that needed to be treated with varenicline for one additional person to successfully quit was ten patients (95\% CI, 8-13). It is well known that the risk of serious CEs in people with stable CVD is $5.57 \%$ per year among smokers. ${ }^{7}$ Svanström et al reported no increased risk of major CEs associated with varenicline compared with bupropion. ${ }^{11}$ However, these studies have attracted some criticism. ${ }^{23,24}$ Recently, in the EUROACTION PLUS study, no CEs attributable to varenicline were reported. ${ }^{25}$ In the current study, we found toxic effects of varenicline on heart and aortic tissue by measuring biochemical, histopathological, and hemodynamic parameters.

Cigarette smoking is one of the strongest contributors to the risks of CVD, including coronary heart disease, stroke, sudden death, peripheral artery disease, and aortic aneurysm. It is well established that smoking induces sympathetic activity, 

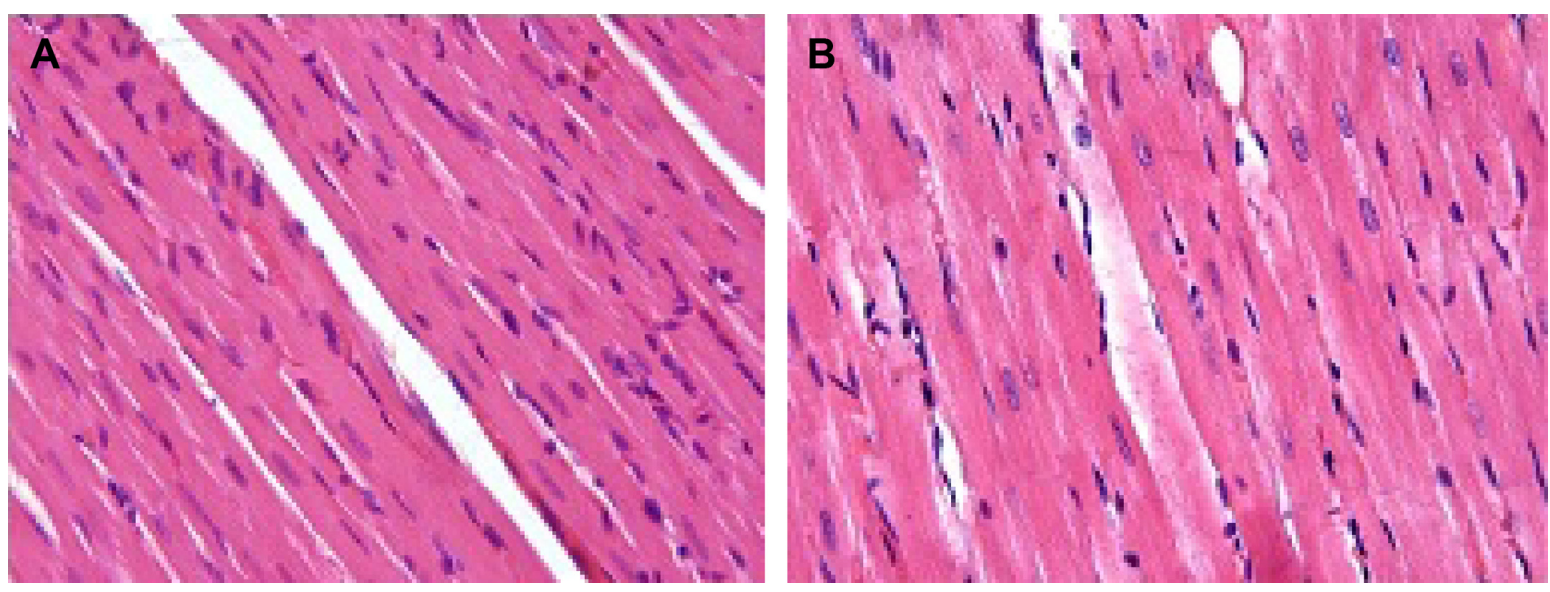

Figure I Appearance of heart tissue in control groups.

Notes: $\mathrm{Cl}(\mathbf{A})$ and $\mathrm{C} 2(\mathbf{B})$ groups. Both had normal heart structure and there were no lesions. H\&E staining; magnification $\times 40$.

Abbreviations: $\mathrm{Cl}$, control group for acute varenicline treatment; $\mathrm{C} 2$, control group for chronic varenicline treatment; $\mathrm{H} \& \mathrm{E}$, hematoxylin and eosin.

increasing HR and BP. ${ }^{26-28}$ Nicotine activates nicotinic acetylcholine receptors in both the sympathetic and parasympathetic ganglia, so it has dual effects and can both increase and reduce HR and MBP values. Considerable reductions in the risk of CVD occur immediately after the discontinuation of cigarette smoking. Alterations in BP, HR, and autonomic nervous function are thought to be responsible for the rapid reduction in the risk of CVD after quitting..$^{29}$ Central nicotinic receptors located in the brainstem are also involved in cardiovascular control. ${ }^{30-32}$ Hence, HR and MBP may be determined by multiple mechanisms. Although these nicotinic agonists have been reported to differ in efficacy, ${ }^{33-39}$ all agonists were capable of producing similar pressor responses with approximately similar increases in MBP $(30 \%-40 \%$ increase over resting baseline) at the doses evaluated in the present study.

Studies have reported that varenicline has high efficacy in its agonist activity at $\alpha 7$ receptor subtypes, and may mediate nicotinic agonist-induced increases in sympathetic activity. 22,40 Jutkiewicz et al reported that although varenicline significantly decreased HR, it could engender all cardiovascular responses. ${ }^{40}$ Our results showed no significant change in HR for both the acute and chronic groups, whereas there was a significant decrease in MBP values in the V2 treatment group compared with the $\mathrm{C} 2$ group. Although the change in $\mathrm{BP}$ was statistically significant, we believe that this result should be disregarded because of the relatively high measurements in the $\mathrm{C} 2$ group. Thus, we consider that in our current study, there was no change in BP, consistent with the results of other studies..$^{29,30,40}$

In the current study, we determined that varenicline exposure induced lipid peroxidation by an increase in MDA levels and reduced the antioxidant defense system via decreases in SOD, CAT, and GPx activity, and reduced GSH levels.
MDA, an indicator of lipid peroxidation, is generated by peroxidation of fatty acids by reactive oxygen species (ROS), and leads to irreversible cell damage ${ }^{41}$ However, under normal physiological conditions, the antioxidant defense systems containing SOD, CAT, GPx, and GSH protect cells against oxidative damage. ${ }^{42}$ Oxidative stress is a condition of imbalance between TBARS and the antioxidant defense system. The deterioration of the balance between the formation rate of oxidant molecules and the antioxidant defense molecules leads to oxidative stress. Membrane lipids, proteins, nucleic acids, and deoxyribonucleic acid (DNA) molecules are the most sensitive cellular components to ROS formation. These free radicals lead to cell injury, resulting in membrane damage, DNA destruction, protease activation, and lipid and protein peroxidation, and thereby the apoptotic and necrotic cell damage that occurs in the heart. ${ }^{43}$

Our data indicated that acute administration of varenicline did not exert oxidative effects on the heart, but chronic administration of varenicline produced AEs on the heart and aortic tissue compared with the $\mathrm{C} 1, \mathrm{C} 2$, and the $\mathrm{V} 1$ groups. MPO, implicated in the pathogenesis of various inflammatory diseases, is a known inflammation marker. ${ }^{44,45}$ Previous studies have shown an association between high MPO levels and adverse cardiovascular outcomes. ${ }^{46,47}$ In the present study, we observed that chronic varenicline exposure caused a significant increase in the levels of MPO in the heart tissue. MPO activity is known to be related to tissue neutrophil accumulation, and Allegra et a ${ }^{48}$ reported that MPO is a sensitive index of tissue neutrophil sequestration. Thus, it seems likely that chronic varenicline exposure can cause inflammation in the heart tissue. However, Kato et $\mathrm{a}^{49}$ showed that vareniclineassisted smoking cessation restores endothelial function, and 

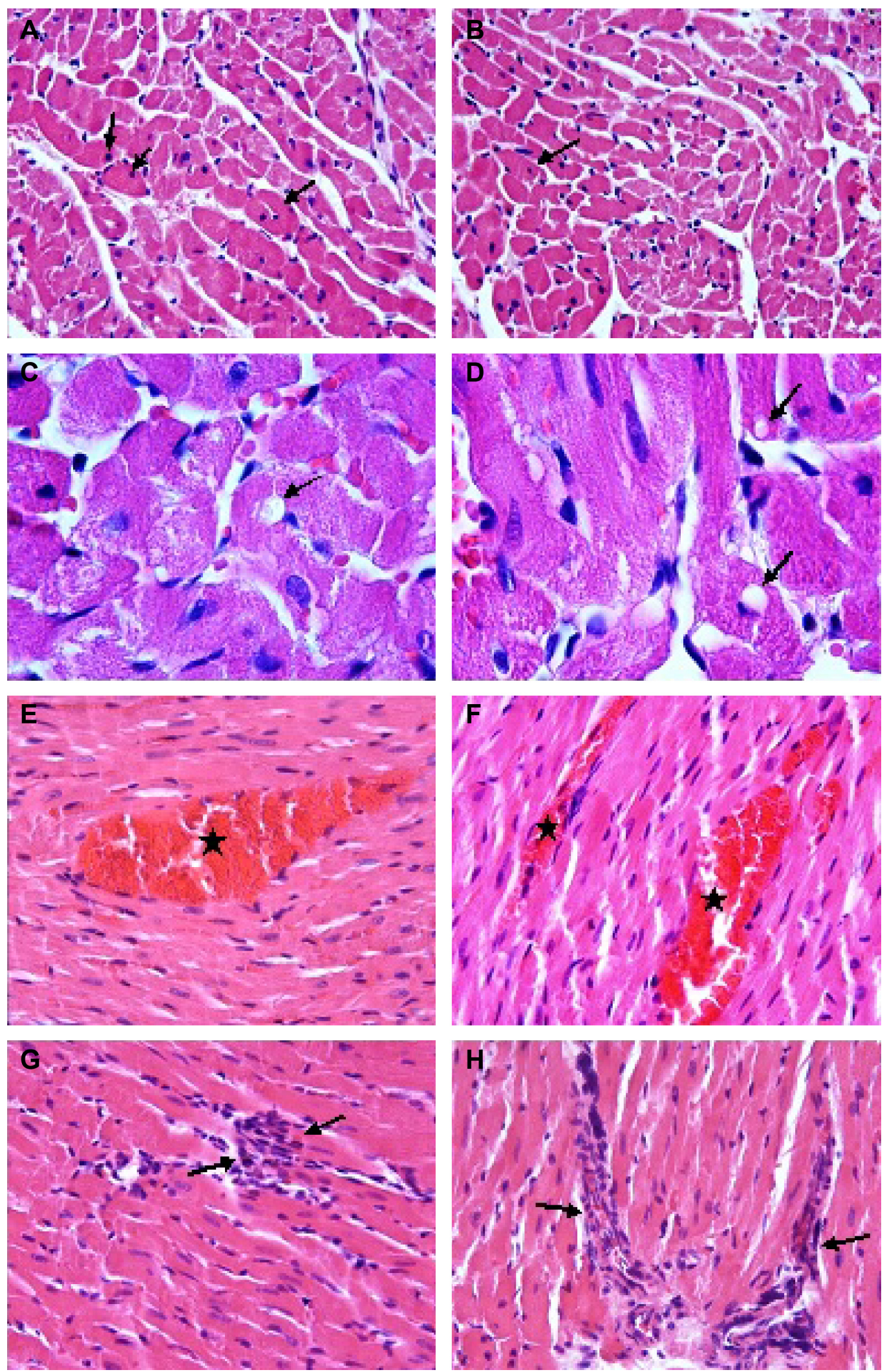

Figure 2 Effect of varenicline treatment.

Notes: VI (A) and V2 (B) groups: appearance of the cytoplasm of cardiomyocytes was eosinophilic and with darker nuclei (arrows); H\&E staining; magnification $\times 40$. VI (C) and V2 (D) groups: some of the cardiomyocytes showed intracytoplasmic vacuoles (arrows). H\&E staining; magnification $\times 100$. VI (E) and V2 (F) groups: notice the interstitial congestion (stars). H\&E staining; magnification $\times 40$. VI (G) and V2 (H) groups: visible inflammatory cell infiltration between cardiomyocytes (arrows). H\&E staining; magnification $\times 40$.

Abbreviations: VI, acute varenicline treatment group; V2, chronic varenicline treatment group; H\&E, hematoxylin and eosin. 
Table 4 Results of semiquantitative histological assessment in all groups

\begin{tabular}{lllll}
\hline Parameters & CI & V I & C2 & V2 \\
\hline $\begin{array}{l}\text { Eosinophilic cytoplasm and } \\
\text { Pyknotic nuclei }\end{array}$ & $0(0-0)$ & $\mathrm{I}(0-\mathrm{I})^{\mathrm{a}}$ & $0(0-0)$ & $\mathrm{I} .5(\mathrm{I}-2)^{\mathrm{b}, \mathrm{c}}$ \\
Intracytoplasmic vacuoles & $0(0-0)$ & $\mathrm{I}(0-2)^{\mathrm{a}}$ & $0(0-0)$ & $\mathrm{I}(\mathrm{I}-2)^{\mathrm{b}, \mathrm{d}}$ \\
Interstitial congestion & $0(0-\mathrm{I})$ & $\mathrm{I}(0-2)^{\mathrm{a}}$ & $0(0-\mathrm{I})$ & $\mathrm{I}(0-2)^{\mathrm{b}, \mathrm{c}}$ \\
Inflammatory cell infiltration & $0(0-0)$ & $\mathrm{I}(0-2)^{\mathrm{a}}$ & $0(0-0)$ & $\mathrm{I}(\mathrm{I}-2)^{\mathrm{b}, \mathrm{d}}$ \\
\hline
\end{tabular}

Notes: Data are presented as score median (range). aSignificant increase $(P=0.000 \mathrm{I})$ vs $\mathrm{Cl}$; ' significant increase $(P=0.000 \mathrm{I})$ vs $\mathrm{C} 2$; 'significant increase $(P=0.000 \mathrm{I})$ vs $\mathrm{VI}$; ${ }^{\mathrm{N}}$ non-significant increase $(P>0.05)$ vs $\mathrm{VI}$.

Abbreviations: $\mathrm{Cl}$, control group for acute varenicline treatment $(\mathrm{n}=5) ; \mathrm{C} 2$, control group for chronic varenicline treatment $(n=5) ; \mathrm{VI}$, acute varenicline treatment group $(n=12) ; V 2$, chronic varenicline treatment group $(n=12)$; vs, versus.

this restoration is associated with decreased oxidative stress; thus, it might be also reduce cardiovascular risk. However, that study had some limitations, including small sample size and lack of a control group. ${ }^{49}$

In the ECG traces in the present study, there was a prolongation of PR interval, resembling decreased atrioventricular conduction velocity, in both the V1 and V2 groups. It is well known that prolongation of the PR interval is associated with an adverse outcome in structural heart disease, whereas it is a benign ECG change in the absence of structural heart disease. ${ }^{50-52}$ Findings from the Framingham Heart Study population have shown that prolonged PR interval is associated with an increased risk of atrial fibrillation and pacemaker implantation. ${ }^{53,54}$ Taking the PR prolongation together with the histopathological findings in both varenicline-treated groups, it appears that the morphological damage characterized by eosinophilic cytoplasm, darker nuclei, intracytoplasmic vacuole generation, hemorrhage (Figure 2E, F) and inflammatory cell infiltration seen in both varenicline groups in the current study adversely affects atrioventricular conduction. Another important finding of the ECG result was the prolonged QT interval noted in the V2 group but not in the V1 group. Acquired QT prolongation on ECG is a well-known repolarization abnormality indicating increased risk for malignant arrhythmia generation and sudden cardiac death (torsade de pointes). ${ }^{55-57}$ Although rat studies have shown good agreement between QT interval prolongation assessments based on rat ECG data and clinical findings in
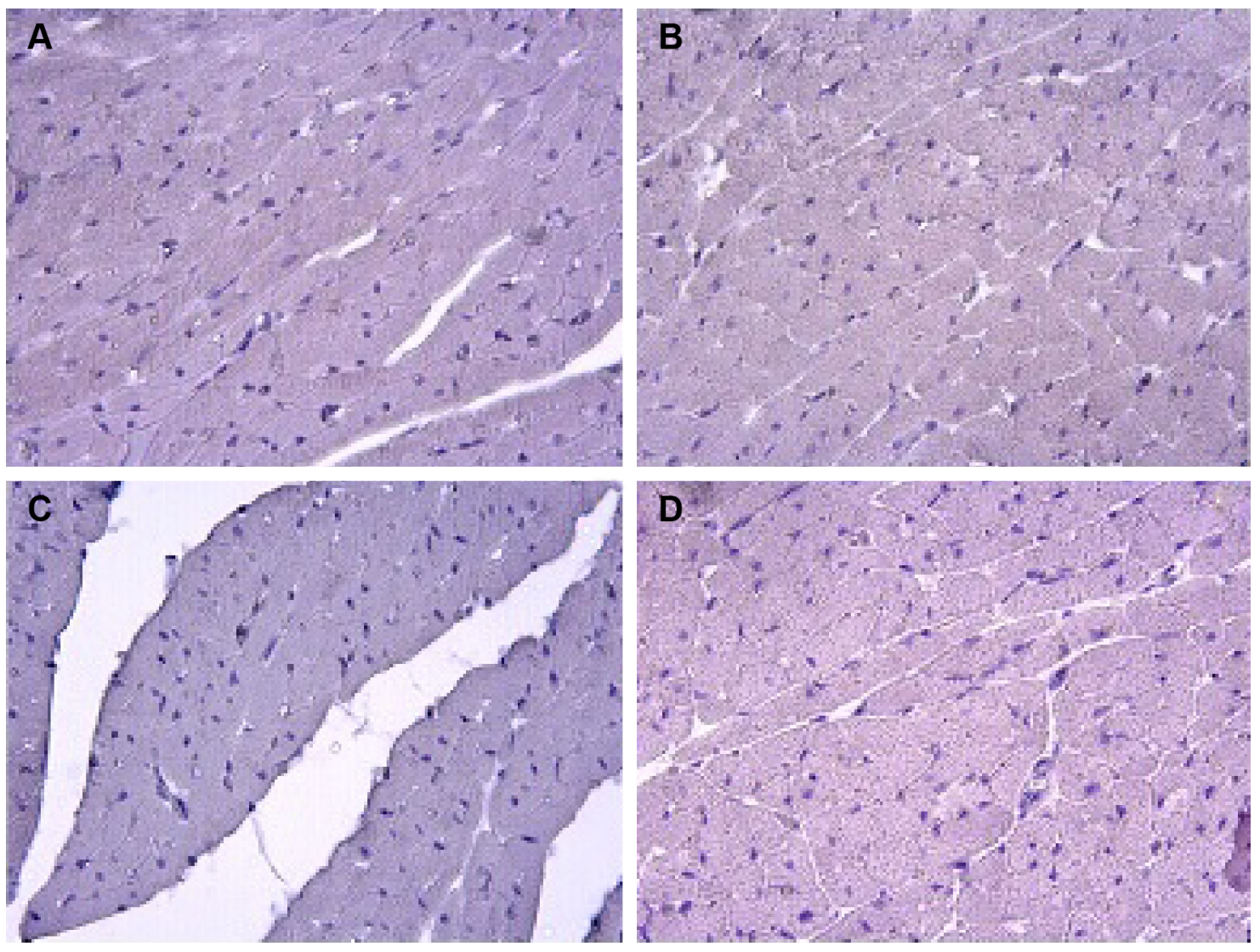

Figure 3 Assessment of caspase-3 immunoreactivity.

Notes: $\mathrm{Cl}(\mathbf{A}), \mathrm{C} 2(\mathbf{B}), \mathrm{VI}(\mathbf{C})$, and V2 (D) groups; no caspase-3 immunoreactivity was seen in the heart cells in any of the groups. Magnification $\times 40$.

Abbreviations: $\mathrm{Cl}$, control group for acute varenicline treatment; $\mathrm{C} 2$, control group for chronic varenicline treatment; $\mathrm{VI}$, acute varenicline treatment group; $\mathrm{V}$, chronic varenicline treatment group. 

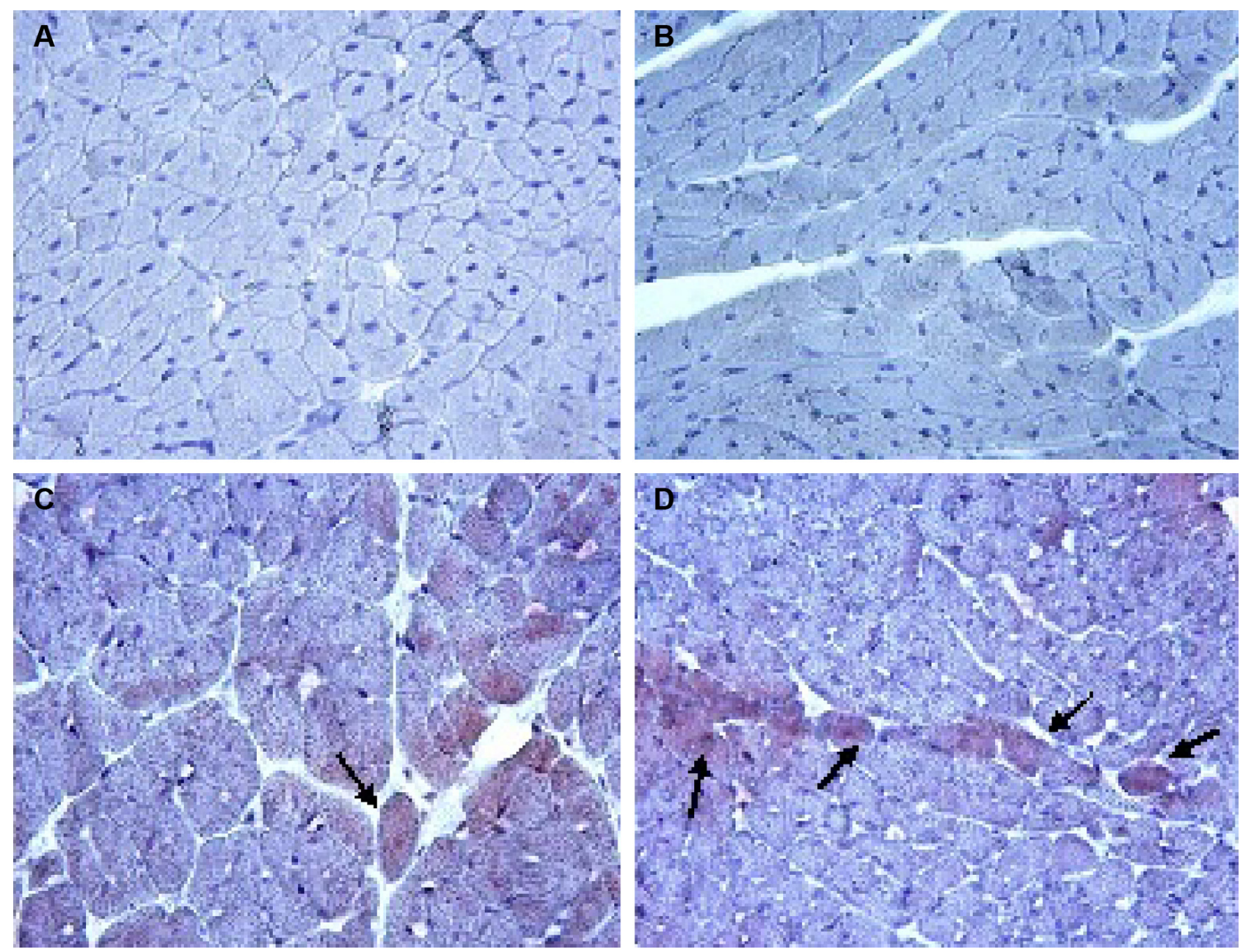

Figure 4 Assessment of caspase-9 immunoreactivity.

Notes: $\mathrm{Cl}(\mathbf{A})$ and C2 (B) groups: caspase-9-positive cells were not seen. $\mathrm{VI}$ (C) and V2 (D) groups: a few caspase-9-positive cells were observed (arrows). Magnification $\times 40$.

Abbreviations: $\mathrm{Cl}$, control group for acute varenicline treatment; $\mathrm{C} 2$, control group for chronic varenicline treatment; $\mathrm{VI}$, acute varenicline treatment group; $\mathrm{V} 2$, chronic varenicline treatment group.
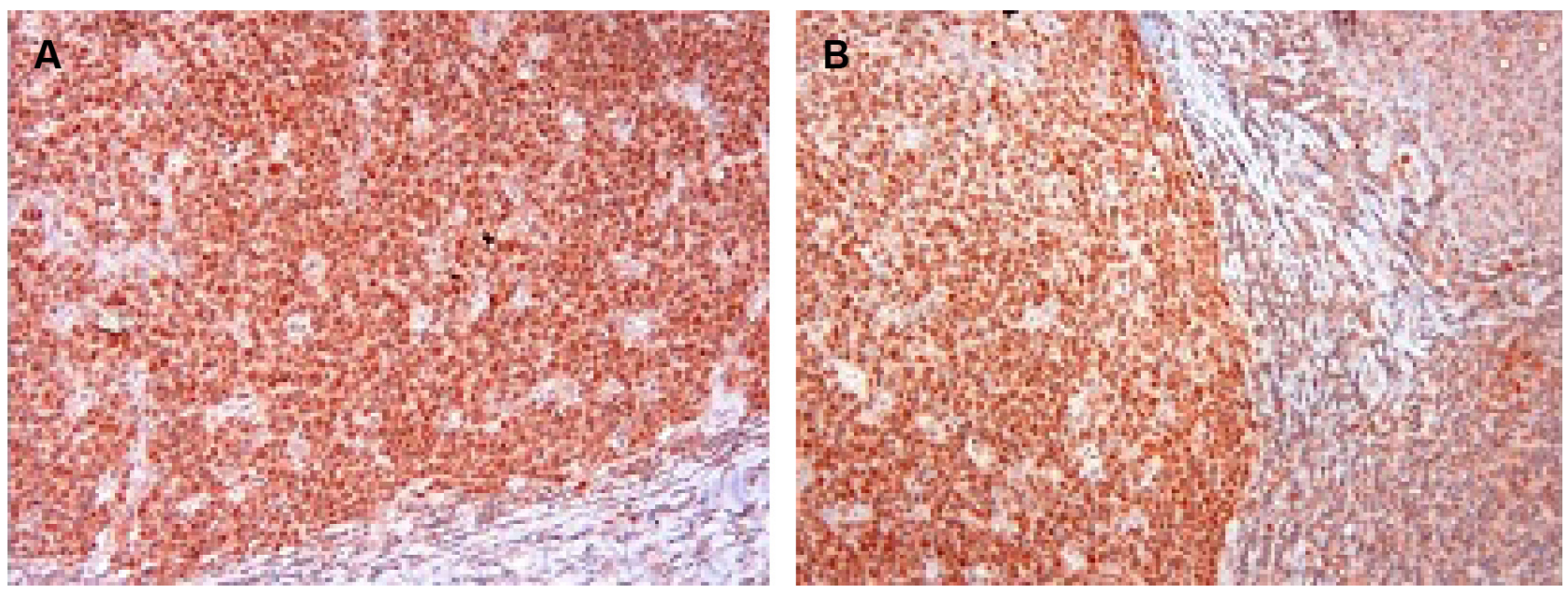

Figure 5 Immunohistochemical staining of human tonsil.

Notes: Anti-caspase-3 antibody (A); anti-caspase-9 antibody (B). 
Table 5 Mean staining intensity of caspase- 9 in heart tissue

\begin{tabular}{lllll}
\hline Parameter & Cl & VI & C2 & V2 \\
\hline Caspase-9 (+) & $0(0-0)$ & $0(0-1)^{\mathrm{a}}$ & $0(0-0)$ & $0(0-2)^{\mathrm{b}, \mathrm{c}}$
\end{tabular}

Notes: a Significant increase $(P<0.000 \mathrm{I})$ vs $\mathrm{Cl}$ group; bsignificant increase $(P<0.000 \mathrm{I})$ vs $\mathrm{C} 2$ group; 'significant increase $(P<0.000 \mathrm{I})$ vs $\mathrm{VI}$ group.

Abbreviations: $\mathrm{Cl}$, control group for acute varenicline treatment $(\mathrm{n}=5)$; $\mathrm{C} 2$, control group for chronic varenicline treatment $(n=5)$; VI, acute varenicline treatment group ( $n=12)$; V2, chronic varenicline treatment group $(n=12)$; vs, versus; + , positive.

humans, these results should be carefully assessed and the existence of differences between rats and humans should be kept in mind. ${ }^{58}$

To our knowledge, there have been no clinical studies about the impact of varenicline on oxygen saturation. Some studies on the neurological effects of varenicline have shown blood oxygenation level-dependent signals pinpointing the oxyhemoglobin and deoxyhemoglobin levels in the blood by functional magnetic resonance imaging. ${ }^{59,60}$ These results suggest detrimental cognitive effects of varenicline treatment. When a smoker is treated with varenicline for smoking cessation, improvement in partial oxygen pressure is expected, especially in the long term. In our present study, we observed a significant decrease in partial pressure of $\mathrm{SO}_{2} \%$.

The histological results for heart tissue reported here showed that the varenicline-treated rats developed extreme cellular damage, eosinophilic cytoplasm, darker nuclei, intracytoplasmic vacuoles, hemorrhage, and inflammatory cell infiltration. Another histological finding of our current study was aortic damage in the varenicline group. Tunica media thickness was determined during the acute phase, and was thicker in both the V1 and V2 groups.

Apoptosis was clearly seen in varenicline-treated heart tissue by immunohistochemical evaluation. Apoptotic cell death can be detected by a number of methods, both in situ and in vitro, but a single specific marker is not sufficient to detect apoptotic cells; therefore, a combination of parameters should always be used to detect apoptosis. ${ }^{61}$ In our present study, both caspase-3 and caspase- 9 were used for determination of apoptosis. Detection of active components of apoptotic pathways such as caspases can help to confirm
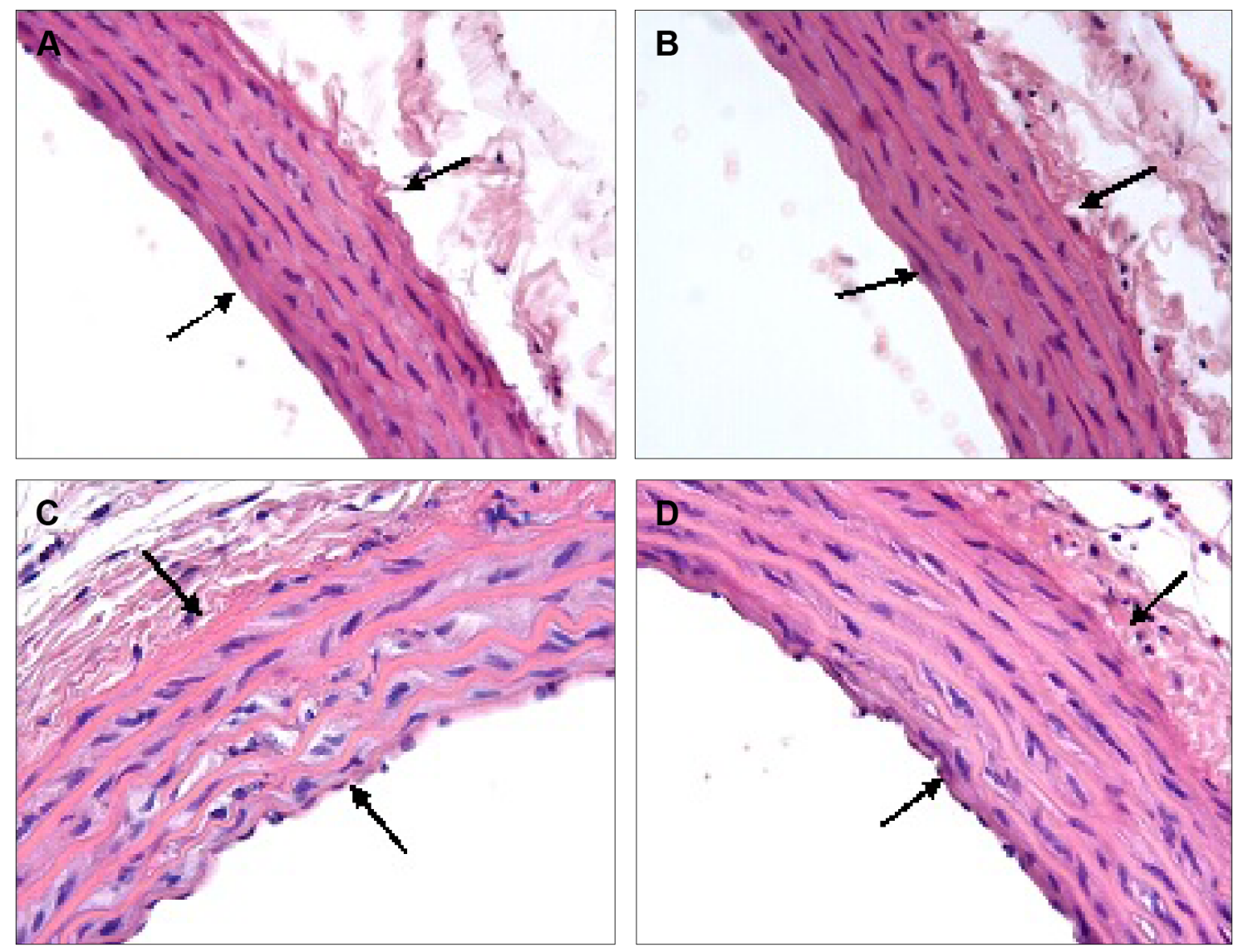

Figure 6 Assessment of aortic wall structure.

Notes: The $\mathrm{Cl}(\mathbf{A})$ and $\mathrm{C} 2(\mathbf{B})$ groups showed the appearance of normal aortic wall structure (arrows). In the VI (C) and V2 (D) groups, medial thickening was prominent (arrows). H\&E staining; magnification $\times 40$.

Abbreviations: $\mathrm{CI}$, control group for acute varenicline treatment; $\mathrm{C} 2$, control group for chronic varenicline treatment; $\mathrm{VI}$, acute varenicline treatment group; $\mathrm{V}$ 2, chronic varenicline treatment group; H\&E, hematoxylin and eosin. 

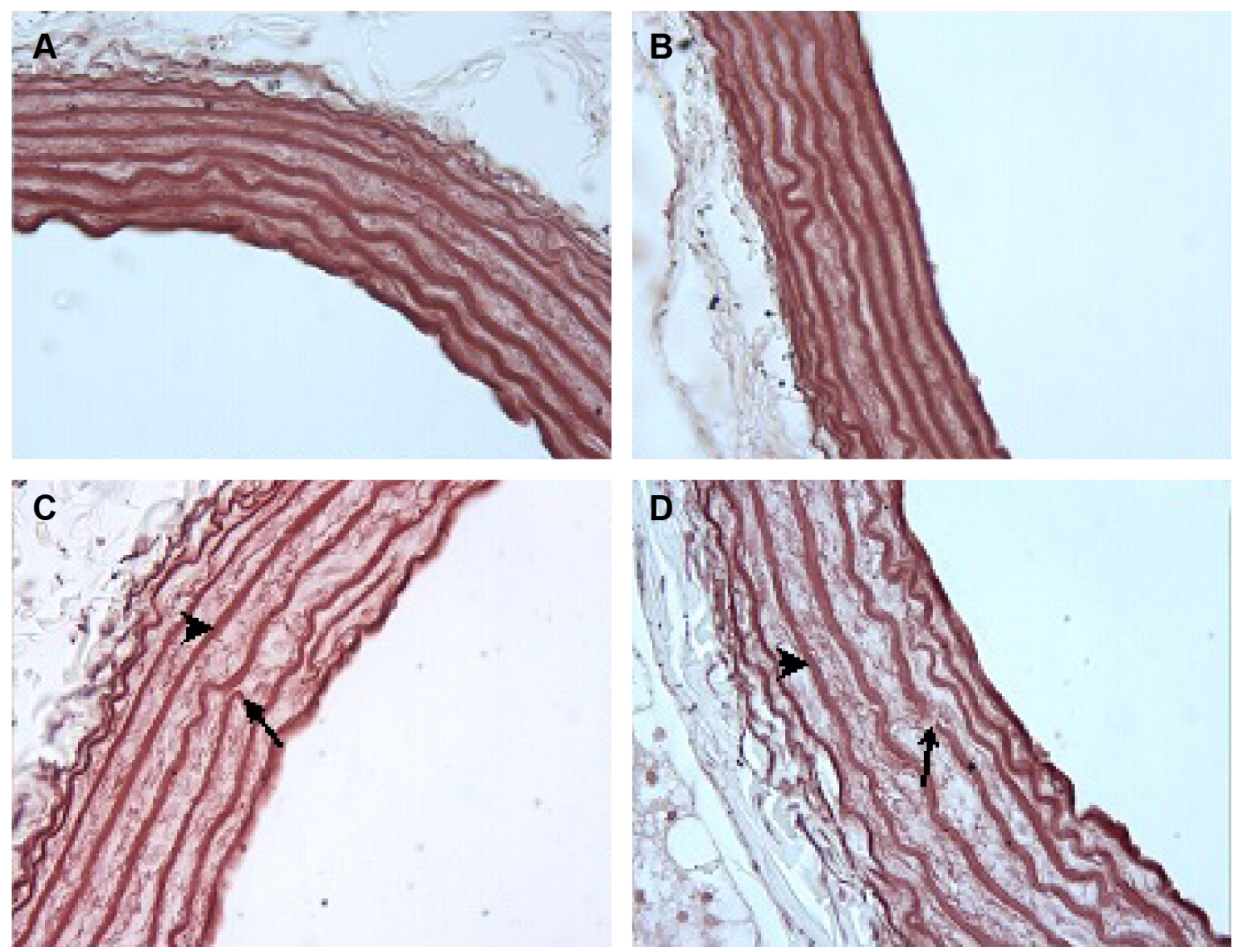

Figure 7 Assessment of elastic lamella.

Notes: $\mathrm{Cl}(\mathbf{A})$ and $\mathrm{C} 2(\mathbf{B})$ groups: note the appearance of wavy and arranged concentrically elastic lamella. VI (C) and V2 (D) groups: note that elastic lamella are smooth (arrowhead) and fragmented (arrow). Orsein staining; magnification $\times 40$.

Abbreviations: $\mathrm{Cl}$, control group for acute varenicline treatment; $\mathrm{C}$, control group for chronic varenicline treatment; $\mathrm{VI}$, acute varenicline treatment group; $\mathrm{V} 2$, chronic varenicline treatment group.

findings. ${ }^{61}$ For this reason, we also determined caspase- 3 and caspase-9 activation. In our study, activation of caspase-3 probably occurred through the mitochondrial apoptotic pathway, as indicated by the presence of caspase- 9 activity in heart sections. ${ }^{62}$ Activation of caspase-3, which in turn cleaves multiple cellular proteins, results in cell death. ${ }^{63}$

Caspase-9 probably represents a direct downstream target of apoptotic proteases activating factor-1 (Apaf-1), and its activation appears critical for the propagation of cell death signals. ${ }^{64}$ In our present study, while there was no caspase-3 immunoreactivity in heart cells in any of the groups, heart

Table 6 Results of semiquantitative morphometric analysis

\begin{tabular}{lllll}
\hline Parameter & CI & VI & C2 & V2 \\
\hline $\begin{array}{l}\text { Mean thickening } \\
\text { of media }(\mu \mathrm{m})\end{array}$ & $76.96 \pm 2.75$ & $88.08 \pm 3.00^{\mathrm{a}}$ & $74.35 \pm 1.43$ & $92.88 \pm 2.85^{\mathrm{b}, \mathrm{c}}$ \\
\hline
\end{tabular}

Notes: a No significant increase $(P>0.05)$ vs $C 1$; b significant increase $(P=0.01)$ vs $C 2$; 'no significant increase $(P>0.05)$ vs $\mathrm{VI}$.

Abbreviations: $\mathrm{Cl}$, control group for acute varenicline treatment $(n=5) ; C 2$, control group for chronic varenicline treatment $(\mathrm{n}=5)$; $\mathrm{VI}$, acute varenicline treatment group $(n=12)$; V2, chronic varenicline treatment group $(n=12)$; vs, versus. cells had positive staining for caspase- 9 in the experimental groups, and this was significantly higher in the V2 group compared with the V1 group. Nevertheless, detection of a single enzyme in the apoptotic cascade does not provide strong evidence as caspase-3 did not stain, only caspase-9. For strong evidence both of them must be stained, so detection of a single caspase staining does not provide strong evidence for apoptosis but single staining may be indicative because it showed statistically significant results versus the control group.

\section{Conclusion}

In conclusion, in the present investigation, we found in vivo acute and chronic cardiovascular findings of varenicline treatment in rats. Chronic (3 months) varenicline treatment caused significant impairment of $\mathrm{SO}_{2} \%$, major ECG changes, and prolongation of PR and QT durations in varenicline-administered rats. In the biochemical analyses, chronic varenicline treatment significantly induced lipid peroxidation and MPO production, 
and reduced antioxidant content (CAT, GPX, and GSH). Moreover, our histopathological observations were in accordance with the biochemical results. However, further studies are needed to elucidate the clinical implications of these changes. Since varenicline is used for cessation of smoking, which is harmful to the whole body, a risk-benefit analysis is necessary, and the results should be compared with the AEs of other smoking cessation drugs.

\section{Acknowledgment}

This study was supported by a grant from The Scientific and Technological Research Council of Turkey (project number 2209/A-2012 to MS).

\section{Disclosure}

The authors report no conflicts of interest in this work.

\section{References}

1. Cahill K, Stead LF, Lancaster T. Nicotine receptor partial agonists for smoking cessation [review]. Cochrane Database Syst Rev. 2011;4: CD006103.

2. Hays JT, Ebbert JO. Varenicline for tobacco dependence. $N$ Engl $J$ Med. 2008;359(19):2018-2024.

3. Oncken C, Gonzales D, Nides M, et al. Efficacy and safety of the novel selective nicotinic acetylcholine receptor partial agonist, varenicline, for smoking cessation. Arch Intern Med. 2006;166(15):1571-1577.

4. Tsai ST, Cho HJ, Cheng HS, et al. A randomized, placebo-controlled trial of varenicline, a selective $\alpha 4 \beta 2$ nicotinic acetylcholine receptor partial agonist, as a new therapy for smoking cessation in Asian smokers. Clin Ther. 2007;29(6):1027-1039.

5. Nides M, Oncken C, Gonzales D, et al. Smoking cessation with varenicline, a selective alpha4beta2 nicotinic receptor partial agonist: results from a 7-week, randomized, placebo- and bupropion-controlled trial with 1-year follow-up. Arch Intern Med. 2006;166(15): 1561-1568.

6. Aubin HJ, Bobak A, Britton JR, et al. Varenicline versus transdermal nicotine patch for smoking cessation: results from a randomised openlabel trial. Thorax. 2008;63(8):717-724.

7. Rigotti NA, Pipe AL, Benowitz NL, Arteaga C, Garza D, Tonstad S. Efficacy and safety of varenicline for smoking cessation in patients with cardiovascular disease: a randomized trial. Circulation. 2010;121(2): 221-229.

8. US Food and Drug Administration [webpage on the Internet]. Chantix ${ }^{\circledR}$ (varenicline): label change - risk of certain cardiovascular adverse events. Available from: http://www.fda.gov/Drugs/DrugSafety/ ucm259161.htm?source=govdelivery. Accessed July 15, 2011.

9. Singh S, Loke YK, Spangler JG, Furberg CD. Risk of serious adverse cardiovascular events associated with varenicline: a systematic review and meta-analysis. CMAJ. 2011;183(12):1359-1366.

10. Prochaska JJ, Hilton JF. Risk of cardiovascular serious adverse events associated with varenicline use for tobacco cessation: systematic review and meta-analysis. BMJ. 2012;344:e2856.

11. Svanström H, Pasternak B, Hviid A. Use of varenicline for smoking cessation and risk of serious cardiovascular events: nationwide cohort study. BMJ. 2012;345:e7176.

12. US Food and Drug Administration [webpage on the Internet]. FDA Drug Safety Communication: safety review update of Chantix ${ }^{\circledR}$ (varenicline) and risk of cardiovascular adverse events. Available from: http://www. fda.gov/Drugs/DrugSafety/ucm330367.htm. Accessed December 12, 2012.
13. Toh S, Baker MA, Brown JS, Kornegay C, Platt R; Mini-Sentinel Investigators. Rapid assessment of cardiovascular risk among users of smoking cessation drugs within the US Food and Drug Administration's Mini-Sentinel program. JAMA Intern Med. 2013;173:817-819.

14. avanikoru.org.tr [homepage on the Internet]. Ankara: Smoking cessation programme, Inc.; c75. Available from: http://havanikoru.org.tr/dosya/ Docs_Tutun_Dumaninin_Zararlari/Tutunle_Mucadele_E1_Kitabi.pdf. Accessed October 30, 2015.

15. Mihara M, Uchiyama M. Determination of malonaldehyde precursor in tissues by thiobarbituric acid test. Anal Biochem. 1978;86:271-278.

16. Sun Y, Oberley LW, Li Y. A simple method for clinical assay of superoxide dismutase. Clin Chem. 1988;34:497-500.

17. Paglia DE, Valentine WN. Studies on the quantitative and qualitative characterization of erythrocyte glutathione peroxidase. J Lab Clin Med. 1967;70:158-169.

18. Wei H, Frenkel K. Relationship of oxidative events and DNA oxidation in Sencar mice to in vivo promoting activity of phorbol ester-type tumor promoters. Carcinogenesis. 1993;14:1195-1201.

19. Aebi H. Catalase. In: Bergmeyer HU, editor. Methods of Enzymatic Analysis. New York, NY: Academic Press; 1974:673-677.

20. Ellman GL. Tissue sulfhydryl groups. Arch Biochem Biophys. 1959;82: $70-77$.

21. Walker MJ, Curtıs MJ, Hearse DJ, et al. The Lambeth Conventions: guidelines for the study of arrhythmias in ischaemia infarction, and reperfusion. Cardiovasc Res. 1988;22:447-455.

22. Mihalak KB, Carroll FI, Luetje CW. Varenicline is a partial agonist at alpha4beta2 and a full agonist at alpha7 neuronal nicotinic receptors. Mol Pharmacol. 2006;70(3):801-805.

23. Samuels L. Varenicline: cardiovascular safety. CMAJ. 2011;183(12): 1407-1408.

24. Smolderen KG, Pelle AJ. Letter by Smolderen and Pelle regarding article, "Efficacy and safety of varenicline for smoking cessation in patients with cardiovascular disease: a randomized trial". Circulation. 2010;122:e445; author reply e446.

25. Jennings C, Kotseva K, De Bacquer D; EUROACTION PLUS Study Group. Effectiveness of a preventive cardiology programme for high CVD risk persistent smokers: the EUROACTION PLUS varenicline trial. Eur Heart J. 2014;35:1411-1420.

26. Tachmes L, Fernandez RJ, Sackner MA. Hemodynamic effects of smoking cigarettes of high and low nicotine content. Chest. 1978;74(3): 243-246.

27. Spohr U, Hofmann K, Steck W, et al. Evaluation of smoking-induced effects on sympathetic, hemodynamic and metabolic variables with respect to plasma nicotine and $\mathrm{COHb}$ levels. Atherosclerosis. 1979; 33(3):271-283.

28. Koch A, Hoffmann K, Steck W, et al. Acute cardiovascular reactions after cigarette smoking. Atherosclerosis. 1980;35(1):67-75.

29. Minami J, Ishimitsu T, Matsuoka H. Effects of smoking cessation on blood pressure and heart rate variability in habitual smokers. Hypertension. 1999;33:586-590.

30. Nadeau RA, James TN. Effects of nicotine on heart rate studied by direct perfusion of sinus code. Am J Physiol. 1967;212(4):911-916.

31. Tseng CJ, Appalsamy M, Robertson D, Mosqueda-Garcia R. Effects of nicotine on brainstem mechanisms of cardiovascular control. J Pharmacol Exp Ther. 1993;265(3):1511-1518.

32. Haass M, Kübler W. Nicotine and sympathetic neurotransmission. Cardiovasc Drugs Ther. 1997;10(6):657-665.

33. Buisson B, Gopalakrishnan M, Arneric SP, Sullivan JP, Bertrand D. Human alpha4beta2 neuronal nicotinic acetylcholine receptor in HEK 293 cells: A patch-clamp study. J Neurosci. 1996;16(24):7880-7891.

34. Eaton JB, Peng JH, Schroeder KM, et al. Characterization of human $\alpha 4 \beta 2$-nicotinic acetylcholine receptors stably and heterologously expressed in native nicotinic receptor-null SH-EP1 human epithelial cells. Mol Pharmacol. 2003;64(6):1283-1294.

35. Coe JW, Brooks PR, Vetelino MG, et al. Varenicline: an alpha4beta2 nicotinic receptor partial agonist for smoking cessation. J Med Chem. 2005;48(10):3474-3477. 
36. Rollema H, Chambers LK, Coe JW, et al. Pharmacological profile of the alpha4beta2 nicotinic acetylcholine receptor partial agonist varenicline, an effective smoking cessation aid. Neuropharmacology. 2007;52(3): 985-994.

37. Smith JW, Mogg A, Tafi E, et al. Ligands selective for alpha4beta2 but not alpha3beta 4 or alpha 7 nicotinic receptors generalise to the nicotine discriminative stimulus in the rat. Psychopharmacology (Berl). 2007; 190(2):157-170

38. LeSage MG, Shelley D, Ross JT, Carroll FI, Corrigall WA. Effects of the nicotinic receptor partial agonists varenicline and cytisine on the discriminative stimulus effects of nicotine in rats. Pharmacol Biochem Behav. 2009;91(3):461-467.

39. Carroll FI, Ma W, Deng L, Navarro HA, Damaj MI, Martin BR. Synthesis, nicotinic acetylcholine receptor binding, and antinociceptive properties of 3'-(substituted phenyl) epibatidine analogues. Nicotinic partial agonists. J Nat Prod. 2009;73(3):306-312.

40. Jutkiewicz EM, Rice KC, Carroll FI, Woods JH. Patterns of nicotinic receptor antagonism II: cardiovascular effects in rats. Drug Alcohol Depend. 2013;131(3):284-297.

41. Montjean D, Ménézo Y, Benkhalifa M, et al. Malonaldehyde formation and DNA fragmentation: two independent sperm decays linked to reactive oxygen species. Zygote. 2010;18(3):265-268.

42. Schiller HJ, Reilly PM, Bulkley GB. Tissue perfusion in critical illnesses. Antioxidant therapy. Crit Care Med. 1993;21:S92-S102.

43. Parlakpınar H, Orum MH, Sagir M. Pathophysiology of myocardial ischemia reperfusion injury: a review. Medicine Science. 2013;2(4): 935-954.

44. Wieland E, Brandes A, Armstrong VW, Oellerich M. Oxidative modification of low density lipoproteins by human polymorphonuclear leukocytes. Eur J Clin Chem Clin Biochem. 1993;31(11):725-731.

45. Daugherty A, Dunn JL, Rateri DL, Heinecke JW. Myeloperoxidase, a catalyst for lipoprotein oxidation, is expressed in human atherosclerotic lesions. J Clin Invest. 1994;94(1):437-444.

46. Mocatta TJ, Pilbrow AP, Cameron VA, et al. Plasma concentrations of myeloperoxidase predict mortality after myocardial infarction. $\mathrm{J} \mathrm{Am}$ Coll Cardiol. 2007;49:1993-2000.

47. Tang WW, Wu Y, Nicholls SJ, Hazen SL. Plasma myeloperoxidase predicts incident cardiovascular risks in stable patients undergoing medical management for coronary artery disease. Clin Chem. 2011; 57:33-39.

48. Allegra M, Furtmüller PG, Regelsberger G, et al. Mechanism of reaction of melatonin with human myeloperoxidase. Biochem Biophys Res Commun. 2001;282:380-386.

49. Kato T, Umeda A, Miyagawa K, et al. Varenicline-assisted smoking cessation decreases oxidative stress and restores endothelial function. Hypertens Res. 2014;37:655-658.
50. Crisel RK, Farzaneh-Far R, Na B, Whooley MA. First-degree atrioventricular block is associated with heart failure and death in persons with stable coronary artery disease: data from the Heart and Soul Study. Eur Heart J. 2011;32:1875-1880.

51. Packard JM, Graettinger JS, Graybiel A. Analysis of the electrocardiograms obtained from 1,000 young healthy aviators; ten year follow-up. Circulation. 1954;10:384-400.

52. Hiss RG, Lamb LE. Electrocardiographic findings in 122,043 individuals. Circulation. 1962;25:947-961.

53. Schnabel RB, Sullivan LM, Levy D, et al. Development of a risk score for atrial fibrillation (Framingham Heart Study): a community-based cohort study. Lancet. 2009;373:739-745.

54. Magnani JW, Johnson VM, Sullivan LM, et al. P wave duration and risk of longitudinal atrial fibrillation in persons $\geq 60$ years old (from the Framingham Heart Study). Am J Cardiol. 2011;107:917-921.

55. Schwartz PJ, Ackerman MJ. The long QT syndrome: a transatlantic clinical approach to diagnosis and therapy. Eur Heart J. 2013;34(40): 3109-3116.

56. Josephson ME, Schibgilla VH. Athletes and arrhythmias: clinical considerations and perspectives. Eur Heart J. 1996;17(4):498-505.

57. Joukar S, Ghorbani-Shahrbabaki S, Hajali V, Sheibani V, Naghsh N. Susceptibility to life-threatening ventricular arrhythmias in an animal model of paradoxical sleep deprivation. Sleep Med. 2013;14(12):1277-1282.

58. Ohtani H, Sato H, Iga T, Kotaki H, Sawada Y. Pharmacokineticpharmacodynamic analysis of the arrhythmogenic potency of a novel antiallergic agent, ebastine, in rats. Biopharm Drug Dispos. 1999;20: 101-106.

59. Wheelock MD, Reid MA, To H, White DM, Cropsey KL, Lahti AC. Open label smoking cessation with varenicline is associated with decreased glutamate levels and functional changes in anterior cingulate cortex: preliminary findings. Front Pharmacol. 2014;5:158.

60. Loughead J, Ray R, Wileyto EP, et al. Effects of the alpha4beta2 partial agonist varenicline on brain activity and working memory in abstinent smokers. Biol Psychiatry. 2010;67(8):715-721.

61. Kanoh M, Takemura G, Misao J, et al. Significance of myocytes with positive DNA in situ nick end-labeling (TUNEL) in hearts with dilated cardiomyopathy: not apoptosis but DNA repair. Circulation. 1999;99: 2757-2764.

62. Parlakpinar H, Sahna E, Acet A, Mizrak B, Polat A. Protective effect of caffeic acid phenethyl ester (CAPE) on myocardial ischemia-reperfusioninduced apoptotic cell death. Toxicology. 2005;209(1):1-14.

63. Baud V, Karin M. Signal transduction by tumor necrosis factor and its relatives. Trends Cell Biol. 2001;11:372-377.

64. Pan G, O'Rourke K, Dixit VM. Caspase-9, Bcl-XL, and Apaf-1 form a ternary complex. J Biol Chem. 1998;273:5841-5845.
Drug Design, Development and Therapy

\section{Publish your work in this journal}

Drug Design, Development and Therapy is an international, peerreviewed open-access journal that spans the spectrum of drug design and development through to clinical applications. Clinical outcomes, patient safety, and programs for the development and effective, safe, and sustained use of medicines are a feature of the journal, which

\section{Dovepress}

has also been accepted for indexing on PubMed Central. The manuscript management system is completely online and includes a very quick and fair peer-review system, which is all easy to use. Visit http://www.dovepress.com/testimonials.php to read real quotes from published authors. 